\title{
The Indian Seaweed Resource: Their Nutritive Importance to Human Beings and Threats
}

\author{
G. S. Temkar ${ }^{1 *}$, A. J. Bhatt ${ }^{1}$ and Arti Joshi ${ }^{2}$
}

${ }^{1}$ College of Fisheries Science, Junagadh Agricultural University, Veraval, Gujarat (362 265), India

${ }^{2}$ Veraval Research Centre, ICAR-Central Institute of Fisheries Technology, Matsya Bhavan, Bhidia, Veraval, Gujarat (362 269), India

\section{Corresponding Author}

G. S. Temkar

e-mail: temkarganesh1990@gmail.com

\author{
Article History \\ Article ID: AR1920 \\ Received in $19^{\text {th }}$ October, 2018 \\ Received in revised form $30^{\text {th }}$ October, 2018 \\ Accepted in final form $31^{\text {st }}$ October, 2018
}

\begin{abstract}
Seaweeds were the microalgae observed along the coastal ocean waters. They were observed near the coastal waters, mostly attached to any substratum. Ecologically they provides living and feeding habitat to the most of the aquatic animals. They are of three types-green, brown and red seaweeds. For human population they are useful for various purposes like food, fertilizers, medicines etc. In the present review article, reported studies from Indian as well as different waters throughout the world were discussed. Overall it was stated that, there was good amount of proximate and minerals composition of some scrutinized seaweed species, so in future it can be considered as food resource. The mineral and proximate composition comparison with terrestrial vegetables plants varieties reports, the good amount of these components in some of the analyzed seaweed species. Presently, the concept of Seaweed Aquaculture is one of the option to increase the seaweed production from country, but the unsuitable environmental and coastal oceanic conditions limits to such activities. To overcome this problem proper study were required and at the moment CMFRI, CSMCRI, NIO, etc. like institutes were came forward and they led research for the development of Seaweed Aquaculture. So this review article describe the importance of seaweeds for future generations as food as well as their medicinal importance, also explains status of the seaweed diversity along the Indian coast. The description about their threats represents how to take control measures over the seaweed cultivation, which will be useful for future seaweed cultivation prospective.
\end{abstract}

Keywords: Seaweed, Indian waters, proximate and mineral composition

\section{Introduction}

As over $70 \%$ of Earth's surface is covered in water, and $97 \%$ of that water is salt water, marine ecosystems are the largest types of ecosystems on the planet. But presently due to increasing population level several human induced activities were making major impact on the remaining $30 \%$ of the land. The human activities like urbanization, industrial development, aquaculture practices etc. were tremendously increasing, which going to causes major harmful impacts. Apart from increased human population causes increased hunger, so to satisfy food requirement marine resources were one of the major attraction. But due to indiscriminate fishing activities those marine fish food resources were depleted fastly in last few decades. So to minimize that pressure the seaweed can play major role as alternative food resource, because of they contains all essential food components viz., nutritional and mineral components, in fact that were more than that of land plants.

Seaweeds are a group of photosynthetic non-flowering plant with no distinguishable root, stem and leaves, those are lives in the sea. Seaweeds are generally known as macroalgae, which are highly evolved and adapt to water environment just as higher plants do to their terrestrial environment. They are found in ocean, as attached to rocks in the intertidal zones, washed up on beaches floating on the oceanic surface and also in giant under water forests. Seaweeds forms an important renewable resource in the marine environment and have been part of human civilization from time immemorial. Taxonomically they are classified under three distinct groups: Chlorophyceae or Chlorophyta - green algae, Phaeophyceae or Phaeophyta - brown algae and Rhodophyceae or Rhodophyta - red algae (MacArtain et al., 2007).

Seaweeds contain variety of trace elements, minerals, protein, iodine, bromine, vitamins and several bioactive substances of economic value as well as also serve both for feeding and breeding grounds of ocean life (Krishnamurthy, 2005). The Indian coastal seaweed resource represents good food importance, some of them contains good protein value and also have all essential amino acids which are not available in vegetable food material (Rao et al., 2007; Syad et al., 2013). The nutrition level is differs from species to species. So knowledge of the biochemical composition of seaweed becomes important (Hawkins and Hartnoll, 1983), for the 
evaluation of potential sources of protein, carbohydrate and lipid for commercial use or for possible human consumption (Chapman and Chapman, 1980; Chennubhotla et al., 2013).

Present survey says that Japan, China, and the Republic of Korea are the largest consumers of seaweed as food, apart from that seaweeds also utilized as food ingredients in many western countries like Iceland, Scotland, Ireland, Maine (USA), Brittany (France), Nova Scotia (Canada), and Wales (Mahadevan, 2015). Loureiro et al. (2015) stated that about nearly $83 \%$ of seaweed resource which is cultured and harvested was consumed by the human beings, some are used as direct food like Undaria pinnatifida (wakame) and Laminaria japonica (kombu), some species as food additives such as carrageenan from Eucheuma spp. and mannitol, alginate, and iodine from $L$. japonica (White and Wilson, 2015). In Japan and China the green seaweeds like Enteromorpha, Ulva, Caulerpa and Codium are utilized as food, they are in the form of fresh salads or cooked as vegetables with rice. The species like Porphyra (Nori), Laminaria (Kombu) and Undaria (Wakame) are utilized along with fish and meat dishes also as soup product (Mohammed, 2015). Apart from food seaweeds also represents medical properties for health and disease control, Mohamed et al. (2012) reported that seaweeds also represents properties like anticancer, antiobesity, antidiabetic, antihypertensive, antihyperlipidemic, antioxidant, anticoagulant, anti-inflammatory, immunomodulatory, antiestrogenic, thyroid stimulating, neuroprotective, antiviral, antifungal, antibacterial and tissue healing etc.

Seaweeds are one of the commercially important marine living resources of India. From earliest time they are used as food, fodder, fertilizer, medical source and phycocolloids source (Levering et al., 1969; Chapman, 1970), presently there is large demand of seaweeds for industrial products like agar, algin and carrageenan which were widely consumed as food throughout the world (Ramalingam et al., 2000). There were many studies noted that certain seaweed which are edible, contain good quantities of protein, lipids, minerals and vitamins (Wong and Cheung, 2000; Norziah and Ching, 2002; Sanchez-Machado et al., 2002). The nutrient contents vary with species, geographical location, season and temperature (Dawes et al., 1993; Kaehler and Kennish, 1996) of the region.

The considerable amount of work has been done on marine algae of the Indian region, the nutritive value of seaweeds lie in the fact that they are rich sources of protein, carbohydrate, lipid, trace elements, minerals, and vitamins (Chennubhotla, 1977, 2016; Kaliaperumal, 2011). They have many essential amino acids including iodine than that of terrestrial plants. Taking into consideration, the ever growing demand for proteinaceous food for human consumption it has become very essential to locate nonconventional resources of nutritive value. The studies on major biochemical constituent's viz., protein, lipid and carbohydrate will give us an idea of the nutritive value of each species of seaweed. High content of proteins, carbohydrates and lipids can be then recommended for food and feed formulations after subjecting them to toxicological studies. Various reports also represents that seaweeds are edible because of they contains good amount of proteins, essential fatty acids, vitamins, and minerals necessary for human growth and development. In India there is not much importance came to seaweed as food resource. But in future surely there were gaining importance of seaweeds for food consumption because of their nutritive values and lack of land resources because of over population, soil erosion, urbanization, industrialization etc.

\section{Seaweed Species Diversity Reported Along Indian Waters}

The earlier report during 2001, Oza and Zaidi (2001) reported total 844 species of seaweed all along the Indian coast. The diversity comprises 216 species of Chlorophyta, 191 species of Pheophyta, 434 species of Rodophyta and 3 species of Xanthophyta. Before that Krishnamurthy and Joshi (1970) were reported 495 seaweed species along Indian coast comprising 36 species of Chlorophyceae, 33 species of Phaeophyceae, 98 species of Rhodophyceae and 6 species of other genera.

The region wise studies were reported are as follows; in recent study of Gujarat coast Jha et al. (2009) reported 198 seaweed species comprises 109 red algae, 54 green algae and 35 brown algae. Along the North and South Andaman waters there were 72 species in 35 genera were reported comprising 29 species of Chlorophyta, 23 species of Pheophyta and 20 species of Rodophyta, another study along Little Andaman reported 52 species (28 genera), consist of 24 green, 10 brown and 18 red seaweed species (Karthik et al., 2013). Veeragurunathan and Sujatha (2013) along Rameswaram coast of Tamil Nadu reported 28 species (8 Chlorophyta, 6 Pheophyta, 11 Rodophyta and 1 Cyanophyta species). Domettila et al. (2013) reported 38 seaweed species which consists of 8 green, 11 brown and 19 red seaweed species along Muttom coastal waters of SW India.

Along Goa coast 145 species of seaweed were reported comprising 41 species of Chlorophyceae, 40 species of Phaeophyceae and 64 species of Rhodophyceae (Pereira and Almeida, 2014). Another study along Southern districts of Tamil Nadu, Sahayaraj et al. (2014) reported 57 species of seaweed (37 genera), which consist of 18 species of Chlorophyta, 14 species of Pheophyta and 25 species of Rodophyta. Along Maharashtra coastal waters of Kunkeshwar and Malvan 40 seaweed species were recorded with 16 Chlorophyceae, 10 Phaeophyceae and 14 Rhodophyceae (Rode and Sabale, 2015).

In Gujarat waters of Kutch regions four islands viz., Chhad, Debeka-Mundeka, Goose and Narrara, 70 seaweed species were recorded which comprises of 24 Green algae, 15 Brown algae and 31 Red algal species (Roy et al., 2015). Naik et al. (2015) along Karwar Bay reported 19 seaweed species with 6 Green, 5 Brown and 8 Red species. Another study along Maharashtra at Uran (Raigad), Navi Mumbai (Pawar, 2017) recorded 19 seaweed species with 7 Chlorophyta, 2 Pheophyta, 7 Rodophyta, 2 Cyanophyta and 1 Charophyta 
species.

\section{Studies Reported on Nutritive Values and Mineral Composition of Some Seaweed Species}

Study about chemical and mineral composition of six potentially edible seaweed species of Yucatán was done by Robledo and Freile-Pelegrin (1997). Ash, protein, fibre, fat, carbohydrates were studied for chemical composition and $\mathrm{Na}, \mathrm{K}, \mathrm{Mg}, \mathrm{Ca}, \mathrm{Fe}, \mathrm{Cu}, \mathrm{Cr}, \mathrm{Zn}, \mathrm{Pb}$ as mineral. Gracilaria cornea, Eucheuma isiforme, Caulerpa racemosa, Codium isthmocladum, Padina gymnospora and Sargassum filipendula were selected species. Ash constituent ranging from 29.06$55.93 \%$. E. isiforme showed the highest protein content (12.10\%), while lowest found in C. isthmocladum (3.50\%). Fat content highest in $C$. isthmocladum and $G$. cornea. Rhodophyta showed high carbohydrate contents. S. filipendula and $P$. gymnospora were characterized by a high mineral content, calcium and magnesium were particularly high. Trace metals ( $\mathrm{Fe}, \mathrm{Pb}, \mathrm{Cu}, \mathrm{Cr}$ and $\mathrm{Zn}$ ) occurred at high levels in all species. So it is concluded that species were potential resource for use of human consumption and alternative human uses.

The study on proximate composition of two subtropical red seaweeds (Hypnea charoides and $H$. japonica) and one green seaweed (Ulva lactuca) was done by Wong and Cheung (2000), they reported that, the ash content was ranged from 21.3 to $22.8 \%$ DW, which was one of the most abundant components in those species but their crude lipid contents was very low (ranged from 1.42 to $1.64 \% \mathrm{DW}$ ). The crude protein content of red seaweed was significantly higher than green seaweed. The all three seaweed proteins contained all essential amino acids which were required as per FAO/WHO.

Rupérez (2002) studied mineral content of edible marine seaweeds, viz., brown seaweed (Fucus vesiculosus, Laminaria digitata and Undaria pinnatifida) and red seaweed (Chondrus crispus and Porphyra tenera). Where he reported that seaweeds contained high ash (21.1-39.3\%) and sulphate (1.3$5.9 \%$ ) content. In brown algae, ash content (30.1-39.3\%) was higher than in red algae (20.6-21.1\%). When compare with edible land plants it observed that marine seaweeds contained higher amounts of both macrominerals ( $\mathrm{Na}, \mathrm{K}, \mathrm{Ca}, \mathrm{Mg}$ ) and trace elements (Fe, Zn, Mn, Cu).

Twenty-two species of edible Hawaiian macroalgae were analyzed for biochemical and mineral composition by McDermid and Stuercke (2003). Study revealed that Halymenia formosa and Porphyra vietnamensis ranked highest in total protein content, most species contained less than $5 \%$ crude lipid, although two Dictyota species had over $16 \%$ crude lipid based on dry weight. Soluble carbohydrates ranged from 4.5 to $39.9 \%$ dry weight. Ash values ranged from $22.4 \%$ to $64.2 \%$. All species contained up to 11 essential mineral elements.

Marinho-Soriano et al. (2006) investigated the chemical composition of red seaweed Gracilaria cervicornis and brown seaweed Sargassum vulgare from Brazil. They reported that protein content varied from $23.05 \pm 3.04 \%$ to $15.97 \pm 3.04 \%$ respectively, with highest value was found in G. cervicornis. Carbohydrate contents of both species varied significantly and the lipid concentrations were the lowest and varied slightly between the two species. Ash content was greater in S. vulgare

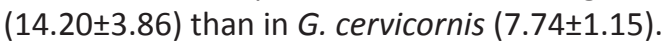

The mineral composition of edible seaweed Porphyra vietnamensis was done by Rao et al. (2007). The mineral concentration ranges found were; Na: 24.5-65.6; K: 1.76-3.19, Ca: 1.40-6.12; Mg: 4.0-5.90 (mg g-1 d wt); Pb: 0.01-0.15; Cr: 0.13-0.22; Co: 0.06-0.20; Fe: 33.0-298; Zn: 0.93-3.27; Mn: 4.22-10.00; Hg: 0.01-0.04; Cu: 0.54-1.05; As: 1.24-1.83; Ni: 0.02-0.25; Cd: 0.14-0.55; Mo: 0.02-0.03 and B: 0.02-0.07 expressed in mg $100 \mathrm{~g}^{-1} \mathrm{dry}$ weight. Study also concluded that mineral composition of $P$. vietnamensis was found relatively higher as compared to the land vegetables as well as to other edible seaweeds, so it can be used as food supplement as a spice to improve the nutritive value in the omnivorous diet.

Manivannan et al. (2008) studied mineral composition of marine macroalge from Mandapam coastal regions, during study seaweeds such as Chlorophyceae (Ulva lactuca and Enteromorpha intestinalis), Phaeophyceae (Turbinaria ornata and Padina gymnospora) and Rhodophyceae (Hypnae valentiae and Gracilaria folifera) were evaluated. Study reported that $P$. gymnospora showed the maximum content of mineral composition such as copper, chromium, iron, lead, sulphur, calcium and potassium content than other seaweeds. $H$. valentiae observed the minimum level of mineral content such as cadmium, iron, magnesium and calcium.

Another study along Gulf of Mannar biosphere reserve was done for mineral composition estimation from some selected species viz. Chlorophyceae (Codium tomentosum, Enteromorpha clathrata and E. compressa), Phaeophyceae (Turbinaria conoides, Colpomenia sinuosa, Sargassum tenerimum and S. wightii) and Rhodophyceae (Acanthophora spicifera; Karthikai Devi et al., 2009). Study stated that The $S$. wightii showed the highest level of mineral composition such as chromium, copper, manganese, nickel, lead and zinc content than other seaweeds, while $A$. spicifera recorded the lowest level of mineral content.

The chemical composition and its seasonal variation of the red seaweed Grateloupia turuturu, from Brittany, France was investigated (Denis et al., 2010). Study stated that on the dry weight basis, this alga was constituted of more than $18 \%$ ash, about $23 \%$ protein, and $2.6 \%$ lipids. The seasonal variations showed that the best period to collect the seaweed for food use is between February and June.

Rohani-Ghadikolaei et al. (2012) done evaluation of the proximate and mineral composition of representative green, brown and red seaweeds from the Persian Gulf of Iran. The species studied for determination from green (Ulva lactuca and Enteromorpha intestinalis), brown (Sargassum ilicifolium and Colpomenia sinuosa) and red (Hypnea valentiae and 
Gracilaria corticata) seaweeds. Results represents that the seaweeds were high in carbohydrate (31.8-59.1\%, dry weight) and ash (12.4-29.9\%) but low in lipid content (1.5-3.6\%). The protein content of red or green seaweeds was significantly higher $(p<0.05)$ compared to brown seaweeds. Studied seaweeds diversity contained higher concentrations of all the minerals examined ( $\mathrm{K}, \mathrm{Mg}, \mathrm{Fe}, \mathrm{Mn}, \mathrm{Cu}, \mathrm{Zn}$ and $\mathrm{Co}$ ) compared to terrestrial vegetables. So it conclude that seaweeds could potentially be used as a food or feed additive in Iran.

Six edible seaweed species viz. Enteromorpha compressa, E. intestinalis, Dictyota dichotoma, Turbinaria ornata, Gracilaria corticata and Hypnea musciformis were analyzed for biochemical composition (Parthiban et al., 2013). Study revealed that protein content ranged from 9.47 to $14.68 \%$, with highest in $T$. ornata and lowest in G. verrucosa. Carbohydrate content of seaweeds ranged between 10.63$28.58 \%$. The maximum carbohydrate content was recorded in $E$. intestinalis and $D$. dichotoma recorded the minimum. The Lipid content of seaweeds varied from 3.15 to $5.30 \%$. The maximum lipid content was recorded in E. intestinalis and minimum in $G$. verrucosa.

The nutritional composition of the two marine algae Gelidiella acerosa (red seaweed) and Sargassum wightii (brown seaweed) revealed that the seaweeds possess high ash content of $0.103 \pm 0.049 \mathrm{~g} \mathrm{~g}^{-1} \mathrm{DW}$ and $0.25 \pm 0.02 \mathrm{~g} \mathrm{~g}^{-1} \mathrm{DW}$, respectively. Nutritional composition analysis showed that the carbohydrate, protein and lipid contents of the seaweeds were high. Evaluation of mineral content demonstrates that the concentration of potassium was high in G. acerosa, whereas S. wightii was found to possess high amount of Sodium. Amino acid composition showed that both the seaweeds possess most of the essential amino acids including valine, methionine, lysine and phenyl alanine. So it suggest that both the seaweeds have greater nutritional value and could be used as excellent nutritional supplements (Syad et al., 2013).

Evaluation of proximate composition of Gracilaria edulis collected from Palk Bay was done by Sakthivel and Devi (2015). They reported that carbohydrate $\left(101.61 \pm 1.8 \mathrm{mg} \mathrm{g}^{-1}\right.$ DW), crude protein $\left(6.68 \pm 0.94 \mathrm{mg} \mathrm{g}^{-1} \mathrm{DW}\right)$ and lipid content $\left(8.3 \pm 1.03 \mathrm{mg} \mathrm{g}^{-1} \mathrm{DW}\right)$ in $\mathrm{G}$. edulis.

Assessment of biochemical composition in a brown seaweed Sargassum wightii correlation with its seasonal variations was done by Kumar et al. (2015). The study revealed that carbohydrate and protein concentrations were highest in March and minimal values were recorded from July through September months. Both protein and carbohydrates were found to be negatively correlated with ash content. Maximum and minimum ash contents were recorded from July $(22.3 \pm 0.12 \%)$ to November $(16.2 \pm 0.08 \%)$, respectively.

Chemical composition of six red, brown and green macroalgae from Buarcos bay in Central West Coast of Portugal was studied by Rodrigues et al. (2015). During study protein and fat content ranged between 14.4 to 23.8 and 0.6 to $3.6 \%$ and some seaweed species gives as good sources of $\mathrm{Ca}, \mathrm{K}, \mathrm{Mg}$ and Fe corroborating their good nutritional value.

\section{Threats and Opportunities for the Indian Seaweed Resources}

The consideration about the world seaweed resource and industrial development there are many more constraints were observed, such as uncertainty in the supply of seaweed resource, apart from overexploitation of resources due to slow growth rates in nature (Dhargalkar and Verlecar, 2009). So to avoid those constraints and to increasing the seaweed production throughout the globe seaweed cultivation is came forward as one of the great opportunity. And if considering the present seaweed cultivation condition throughout the world it will be stated that seaweed cultivation is more extensive than that of fish culture (Mouritsen, 2013), there was about $13 \mathrm{mt}$ of wet seaweed was harvested every year from about 40 countries, the maximum yield is comes from China (95\%) and remaining from North and South Korea, Japan, the Philippines, Chile, Norway, Indonesia, United States of America, and India. Out of the total cultivation there was about $83 \%$ seaweed is used for human consumption (Craigie, 2011).

Along Indian waters the Gulf of Mannar is the richest area for the seaweed diversity. But local fisher folk mostly women were the major threat to the seaweed resource, because they harvest the resources without giving them time for their replenishment. This overfishing activities shows some species depletion from the nature. The climate change and bacterial activities along the coastal waters impacted on cultivated seaweed species by forming disease like ice-ice. The Gulf of Kutch contributes to the maximum species and biomass of seaweeds for the west coast of India. The southern coast of Gulf supports luxuriant growth of marine algae while the northern shore has very poor algal biodiversity due to high turbidity. Apart from high current waters limits the cultivation activities of seaweeds. But still there is development of some of the suitable sites along Gujarat waters for seaweed cultivation like Miyani, Okha, Mithapur etc.

\section{Conclusion}

Seaweed is one of the major emerging important resource for humans. As the fisheries resources goes on decreasing on large scale due to overfishing it becomes necessary to find out alternative source to fulfilling the nutritional requirements of growing population, so in that case the seaweed resources were good alternative option. So in future seaweed can becomes as one of the major valuable and important resource for human beings.

\section{Acknowledgement}

The authors are grateful to the Dr. A. Y. Desai, Dean and Principal, College of Fisheries, Veraval for having granted permission to conduct this programme. Authors are also thanks to Junagadh Agricultural University, Gujarat for granting 
permission to do research on seaweed. This review article is the part Ph.D. research work.

\section{References}

Chapman, V.J., 1970. Seaweeds and their uses. ( $\left.2^{\text {nd }} E d n.\right)$, The Camelot Press Ltd., Methuen \& Co Ltd., London and Southampton, 63-85.

Chapman, V.J., Chapman, D.J., 1980. Seaweeds and their Uses. (3rd edn.), Chapman and Hall, New York, 34.

Chennubhotla, V.S.K., 1977. Food from the sea: Food from the seaweeds. Seaweed Export Journal 9, 1-4.

Chennubhotla, V.S.K., 2016. Marine algae - their distribution, resources and utilisation (S4). International Conference on Advances in Algal Biotechnology, V.I.T. University, Vellore.

Chennubhotla, V.S.K., Rao, M.U., Rao, K.S., 2013. Commercial importance of marine macroalgae. Seaweed Research and Utilisation 35, 118-128.

Craigie, J.S., 2011. Seaweed extract stimuli in plant science and agriculture. Journal of Applied Phycology 23, 321-335. DOI: https://doi.org/10.1007/s10811-010-9560-4

Dawes, C.J., Lluisma, A.O., Trono, G.C., 1993. Clonal propagation of Eucheuma denticulatum and Kappaphycus alvarezii for Philippine seaweed farms. Hydrobiologia 260/261, 379383. DOI: $10.1007 / B F 00049044$.

Denis, C., Morançais, M., Li, M., Deniaud, E., Gaudin, P., Wielgosz-Collin, G., Barnathan, G., Jaouen, P., Fleurence, J., 2010. Study of the chemical composition of edible red macroalgae Grateloupia turuturu from Brittany (France). Food Chemistry 119, 913-917. DOI: 10.1016/j. foodchem.2009.07.047.

Dhargalkar, V.K., Verlecar, X.N. 2009. Southern Ocean seaweeds: A resource for exploration in food and drugs. Aquaculture 287, 229-242. DOI:10.1016/j. aquaculture.2008.11.013.

Domettila, C., Brintha, T.S.S., Sukumaran, S., Jeeva, S., 2013. Diversity and distribution of seaweeds in the Muttom coastal waters, south-west coast of India. Biodiversity Journal 4, 105-110.

Hawkins, S.J., Hartnoll, R.G., 1983. Grazing of intertidal algae by marine invertebrates. Oceanography and Marine Biology: An Annual Review 21, 195-282.

Jha, B., Reddy, C.R.K., Thakur, M.C., Rao, M.U., 2009. Seaweeds of India, the Diversity and Distribution of Seaweeds of Gujarat Coast. Developments in Applied Phycology Springer Dordrecht 3, 216.

Kaehler, S., Kennish, R., 1996. Summer and Winter Comparisons in the Nutritional Value of Marine Macroalgae from Hong Kong. Botanica Marina 39, 11-17. DOI: 10.1515/ botm.1996.39.1-6.11

Kaliaperumal, N., 2011. Seaweed products of commercial importance-Their raw materials distribution, resources, production and utilisation. In: Souvenir, Natl. Conference on Algae and Algal Products. Sathyabama University,
SRUA and KIA, 39-49.

Karthik, P., Mohanraju, R., Ramesh, C., Murthy, K.N., 2013. Distribution and diversity of seaweeds in North and South Andaman Island. Seaweed Research and Utilization 35, 8-16.

Karthikai Devi, G., Thirumaran, G., Manivannan, K., Anantharaman, P., 2009. Element Composition of Certain Seaweeds from Gulf of Mannar Marine Biosphere Reserve; Southeast Coast of India. World Journal of Dairy \& Food Sciences 4, 46-55.

Krishnamurthy, V., 2005. Seaweeds: Wonder plants of the sea. Aquaculture Foundation of India, 30.

Krishnamurthy, V., Joshi, H.V., 1970. A check-list of Indian marine algae. Central Salt \& Marine Chemicals Research Institute, Bhavnagar, 36.

Kumar, S., Sahoo, D., Levine, I., 2015. Assessment of nutritional value in a brown seaweed Sargassum wightii and their seasonal variations. Algal Research 9, 117-125. DOI: 10.1016/j.algal.2015.02.024

Levering, T., Hoppe, H.A., Schmid, O.J., 1969. Marine Algae. A survey of research and Utilization. Granm be Gruyter \& Co., Hamburg, 1-421.

Loureiro, R., Gachon, C.M.M., Rebours, C., 2015. Seaweed cultivation: potential and challenges of crop domestication at an unprecedented pace. New Phytologist 206, 489-492. DOI: 10.1111/nph.13278

MacArtain, P., Gill, C.I.R., Brooks, M., Campbell, R., Rowland, I.R., 2007. Nutritional value of edible seaweeds. Nutrition Reviews 65, 535-543. DOI: https://doi. org/10.1111/j.1753-4887.2007.tb00278.x

Mahadevan, K. 2015. Seaweeds: a sustainable food source. In: Seaweed Sustainability: Food and Non-Food Applications (Eds: Tiwari, B.K. and Troy, D), 347-367. DOI: 10.1016/ B978-0-12-418697-2.00013-1

Manivannan, K., Karthikai Devi, G., Thirumaran, G., Anantharaman, P., 2008. Mineral Composition of Marine Macroalge from Mandapam Coastal Regions; Southeast Coast of India. American-Eurasian Journal of Botany 1, 58-67.

Marinho-Soriano, E., Fonseca, P.C., Carneiro, M.A.A., Moreira, W.S.C., 2006. Seasonal variation in the chemical composition of two tropical seaweeds. Bioresource Technology 97, 2402-2406. DOI: 10.1016/j. biortech.2005.10.014.

McDermid, K.J., Stuercke, B., 2003. Nutritional composition of edible Hawaiian seaweeds. Journal of Applied Phycology 15, 513-524. https://link.springer.com/article/10.1023 \%2FB\%3AJAPH.0000004345.31686.7f.

Mohamed, S., Hashim, S.N., Rahman, H.A., 2012. Seaweeds: A sustainable functional food for complementary and alternative therapy. Trends in Food Science \& Technology 23, 83-96. DOI:10.1016/j.tifs.2011.09.001.

Mohammed, G., 2015. Current trends and Prospects of Seaweed Farming in India. Course manual of Winter 
School on Technological Advances in Mariculture for Production Enhancement and Sustainability, 78-84.

Mouritsen, O.G., 2013. Seaweeds: Edible, Available \& Sustainable. University of Chicago Press, Chicago, IL.

Naik, U.G., Beligiriranga, V., Haragi, S.B., 2015. Seaweeds of Karwar Bay, Arabian Sea, West Coast of India - A Diversity Profile. International Journal of Science and Nature 6, 728-732.

Norziah, M.H., Ching, C.Y., 2002. Nutritional composition of edible seaweeds Gracilaria changgi. Food Chemistry 68, 69-76. DOI: 10.1016/S0308-8146(99)00161-2.

Oza, R.M., Zaidi, S.H., 2001. A revised checklist of Indian marine algae. Central Salt and Marine Chemicals Research Institute, Bhavnagar, 296.

Parthiban, C., Saranya, C., Girija, K., Hemalatha, A., Suresh, M., Anantharaman, P., 2013. Biochemical composition of some selected seaweeds from Tuticorin coast. Advances in Applied Science Research 4, 362-366.

Pawar, P.R., 2017. Distribution Pattern \& Species Diversity of Seaweeds at Uran (Navi Mumbai), West Coast of India. International Journal of Pure and Applied Zoology 5, 25-32.

Pereira, N., Almeida, M.R., 2014. A preliminary checklist of marine algae from the coast of Goa. Indian Journal of Geo-Marine Sciences 43, 655-665.

Ramalingam, J.R., Kaliaperumal, N., Kalimuthu, S., 2000. Seaweed exploitation in India. Seaweed Research and Utilization 22, 75-80.

Rao, P.V.S., Mantri, V.A., Ganesan, K., 2007. Mineral composition of edible seaweed Porphyra vietnamensis. Food Chemistry 102, 215-218. DOI: 10.1016/j. foodchem.2006.05.009

Robledo, D., Freile-Pelegrin, Y., 1997. Chemical and Mineral Composition of Six Potentially Edible Seaweed Species of Yucatan. Botanica Marina 40, 301-306. DOI: 10.1515/ botm.1997.40.1-6.301

Rode, S., Sabale, A., 2015. Diversity of seaweeds from Malvan and Kunakeshwar in Sindhudurg District of Maharashtra. Indian Journal of Applied Research 5, 413-415.

Rodrigues, D., Freitas, A.C., Pereira, L., Rocha-Santos, T.A.P., Vasconcelos, M.W., Roriz, M., Rodriguez-Alcala, L.M., Gomes, A.M.P., Duarte, A.C., 2015. Chemical composition of red, brown and green macroalgae from Buarcos bay in Central West Coast of Portugal. Food Chemistry 183, 197-207. DOI: 10.1016/j.foodchem.2015.03.057.

Rohani-Ghadikolaei, K., Abdulalian, E., Ng, W.K., 2012.
Evaluation of the proximate, fatty acid and mineral composition of representative green, brown and red seaweeds from the Persian Gulf of Iran as potential food and feed resources. Journal of Food Science and Technology 49, 774-780. DOI: 10.1007\%2Fs13197-0100220-0.

Roy, S., Salvi, H., Brahmbhat, B., Vaghela, N., Das, L., Pathak, B., 2015. Diversity and distribution of seaweeds in selected reefs and island in Gulf of Kachchh. Seaweed Research and Utilization 37, 12-19.

Ruperez, P., 2002. Mineral content of edible marine seaweeds. Food Chemistry 79, 23-26. DOI: 10.1016/S03088146(02)00171-1.

Sahayaraj, K., Rajesh, S., Asha, A., Rathi, J.M., Raja, P., 2014. Distribution and diversity assessment of the marine microalgae at four southern districts of Tamil Nadu, India. Indian Journal of Geo-Marine Sciences 43, 607-616.

Sakthivel, R., Devi, K.P., 2015. Evaluation of physicochemical properties, proximate and nutritional composition of Gracilaria edulis collected from Palk Bay. Food Chemistry 174, 68-74. DOI: 10.1016/j.foodchem.2014.10.142.

Sanchez-Machado, D.I., Lopez-Hernandez, J., Paseiro-Losada, P., 2002. High-performance liquid chromatographic determination of $\alpha$-tocopherol in macroalgae. Journal of Chromatography A 976, 277-284. DOI: 10.1016/S00219673(02)00934-2.

Syad, A.N., Shunmugiah, K.P., Kasi, P.D., 2013. Seaweeds as nutritional supplements: Analysis of nutritional profile, physicochemical properties and proximate composition of $G$. acerosa and S. wightii. Biomedicine \& Preventive Nutrition 3, 139-144. DOI: 10.1016/j. bionut.2012.12.002.

Veeragurunathan, V., Sujatha, G., 2013. Seasonal changes in distribution and standing crop of marine algae at Rameswaram coast, Tamil Nadu. Seaweed Research and Utilization 35, 41-54.

White, W.L., Wilson, P., 2015. World seaweed utilization. In: Seaweed Sustainability: Food and Non-Food Applications (Eds.: Tiwari, B.K. and Troy, D), 7-25. DOI: 10.1016/B9780-12-418697-2.00002-7

Wong, K.H., Cheung, P.C.K., 2000. Nutritional evaluation of some subtropical red and green seaweeds: Part Iproximate composition, amino acid profiles and some physico-chemical properties. Food Chemistry 71, 475482. DOI: 10.1016/S0308-8146(00)00175-8. 